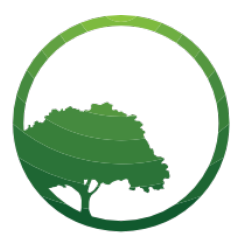

Business \& Social Science IJRBS

\section{Research in Business and Social Science}

IJRBS Vol 8 No 4, ISSN: 2147-4478

Contents available at www.ssbfnet.com/ojs

\title{
Effect of Organizational Culture on Organizational Citizenship Behavior with Organizational Commitment as a Mediator
}

\section{Mira Sekar Arumi}

Bhayangkara Jakarta Raya University, Faculty of Psychology, Indonesia.

ORCID ID: 0000-0002-4668-858X

\section{Neil Aldrin}

Corresponding Author: Bhayangkara Jakarta Raya University, Faculty of Psychology, Indonesia.

ORCID ID: 0000-0001-8990-4695

\section{Tri Ratna Murti}

Persada Indonesia YAl, University, Faculty of Psychology, Indonesia.

\begin{abstract}
The contribution of organizational culture to the organization which includes the uniqueness of values, behavior, and psychology is needed by the organization. It also includes trust, experience, ways of thinking, and organizational expectations. Improving employee behavior into organizational citizenship behavior is needed by every organization. To bring OCB to employees, a well-formed commitment is needed. This study uses a quantitative approach to test 3 hypotheses using path analysis to see the role of mediation. Respondents numbered 169 in this study. The results found in this study are that mediators play a maximum role between organizational culture and OCB.
\end{abstract}

Key words: Organizational Culture, Organizational Commitment, Organizational Citizenship Behavior (Ocb), Employee

Submitted: 08.06.2019 - Accepted: 24.06.2019

\section{Introduction}

Every organization needs to pay attention to the importance of organizational culture because of this achieve overall organizational success. So, it should be considered why the organizational culture needs to be developed, or not, by every organization. When organizations try to manage change throughout their organizations, organizational culture is very important. This change not only changes the process and structure in the organization but also includes the culture within the organization (Mohant \& Rath, 2012). Many researchers stated from the results of their research that organizations that have a good and strong 
organizational culture are very effective and achieve their targets of success compared to those who have a weak organizational culture (Cameron \& Freeman, 1991; Deal \& Kennedy, 1983). According to Schein, (2010), culture is something that is abstraction, but cultural strength can be created if the organization is aware of it. Our lives is always surrounded by the dynamic phenomenon of culture. It is constantly enforced and created by our interactions with others, and continuously shaped by leader behavior as well as structures, routines, rules, and norms. Schein (2010) further said that organizations need to understand what is good for their organizations. When an organization is able to understand its culture well, the organization can understand itself better.

Organizational culture is a system of meanings, values and beliefs that are included in the organization which are references to actions and distinguish one organization from another. According to Hofstede, (2008) organizational culture can be defined as collective programming of thoughts that distinguish members from one organization from another. There are seven cultural dimensions (power distance, individualism versus collectivism, masculinity versus femininity, uncertainty versus certainty avoidance, long-term versus shortterm orientation, indulgence against restraint, and monumentalism versus self-avoidance) in the corporate character of this book (Akopova \& Przhedetskaya, 2016; Sultanova \& Chechina, 2016).

Organizational behavior as a discipline tries to explain human behavior, reasons for various types of behavior, advantages and disadvantages. As a behavioral discipline, organizational behavior is faced with phenomena that affect the work of individuals, teams, and groups in organizations, including motivation. The aim is to increase the effectiveness and efficiency of the organization by using the most important production factor, namely human factors. Organizational culture in a certain way defines employee behavior, attitudes, and values. Creating an adequate organizational culture where success, teamwork, creativity, loyalty, communication, and other values are important is half the way to organizational success. Every employee must be interested in achieving organizational goals because it helps in achieving personal goals that produce overall satisfaction (Veličkovska, 2017).

Organizational commitment is needed for all its employees, this is inseparable from how the existing organizational culture. According to Luthans, (2006) organizational commitment is an attitude that reflects employee loyalty to the organization. It is also an ongoing process where members convey their concerns to the organization, success and continuous progress as well. Commitment to the organization can be reflected in the implementation of duties and functions in the implementation of the organization's daily program. One form of implementation of commitment to the organization is the treatment of time in the form of attendance at the work site in order to provide excellent service including participation in committees in institutional activities and other related activities (Khalik, Hardhienata, \& Sunaryo, 2016).

\section{Literature Review}

\section{Organizational Culture}

Organizational culture is always considered an important topic and is never out of date. Organizational culture arises from each employee whose interactions create rituals, common language, and ultimately a behavior code is created to be able to help or hinder the organization's goals (Aly, Badawy, Kamel, \& Hussein, 2016). Organizational culture consists of a set of values, beliefs, customs, principles and ways of thinking possessed by their members, dimensions, components, and several variables for organizational culture are presented in research variables and indicators of organizational culture in two dimensions and structural behavior is studied (Markoczylivia \& Xin, 2004).

According to Aldrin \& Yunanto (2019), culture is defined when a group of people who live in the same environment have the same attitudes and behaviors. The research conducted by Aldrin \& Yunanto (2019), found that even though employees might feel positively about the organizational culture, it does not automatically encourage them to conduct organizational citizenship behaviour. According to Balay \& Otek, (2010), organizational culture is also conceptualized as a set of ideologies, philosophies, values, behaviors, attitudes and shared norms in an organization. In line with Zeyada, (2008), who argues that organizational culture is also characterized by a set of characteristics derived from general cultural characteristics on the one hand, and administrative organizations, other characteristics. Thus organizational culture can be 
competitive if they effectively deal with changes in the external environment, maintaining internal consistency (Ubius \& Alas, 2009). Furthermore Schein (2010), emphasizes that culture gives us language, and language provides meaning in our daily lives. So that culture can be regarded as the basis of the social order in which we live and the rules that we obey.

From some existing theoretical concepts about culture, we can see that with a conceptualized culture it can help us to get an explanation of the phenomenon of organizational culture. So that we will not be confused with the various behaviors of irrational people. With this understanding, we can better understand more about a group of people or organizations about the dynamics of organizational culture that can be said to be different or difficult to change.

\section{Organizational Commitment}

Organizational commitment issues attract a lot of researchers 'interest in finding out ways to increase employees' intention to commit to their work (Naiemah et al., 2017). Research conducted by Azizi, et al., (2014) provides results and the fact that high organizational commitment will bring and provide positive results for the organization. Organizational commitment is the willingness of employees to identify the goals and values of the organization where they work and sacrifice for the organization.

In the concept of Durna \& Eren (2005), organizational commitment is an important factor for workers to adopt organizational goals, want to continue working in the organization, participate in management and organizational activities, and have creative and innovative attitudes to the organization. According to Ozdem (2012), the issue of organizational commitment needs to be observed and prioritized to keep successful workers continuing to provide maximum results for the organization. In line with what was conveyed by Saraswati \& Sulistiyo (2017), where organizational commitment is the belief and desire of all employees to continue to grow with the organization and maintain every employee in the organization. Organizational commitment how employees align their role in the organization in which they are in it (Robbins \& Judge, 2007).

Organizational commitment is the bond of experience of employees with their organizations. In general, employees who are committed to their organization generally feel a good relationship with their organization, feel right with them, and feel they understand the goals of the organization. These type of employees are more determined in their work, which becomes their added value. They tend to show relatively higher productivity and are more proactive in offering their support.

\section{Organizational Citizenship Behavior (OCB)}

Organizational citizenship behavior (OCB) is defined as behavior that exceeds the formal role determined and is not mentioned in the job description. They are optional behavior, they are not considered in appreciation or judgment. Organizational citizenship behavior towards organizations (OCB) is all behavior that is targeted to benefit the organization as a whole or certain departments such as volunteering to attend events that benefit the company, avoid complaining at work and preserve available resources (Aly et al., 2016). According to Ghashghaeinia \& Hafezi (2015), the main research conducted in the field of organizational citizenship behavior is more to identify the responsibilities or behaviors that employees have in the organization, but are often overlooked. In line with what was conveyed by Organ, Podsakoff, \& MacKenzie (2005), the behavior of organizational citizenship (OCB) contributes to innovation, resource transformation, and adaptability in environments that require complex, team-oriented work, which ultimately increases efficiency and the effectiveness of the entire organization. OCB expresses the organization at its goals and values. This gives the organization's strength, motivation and resources and promotes the interests of the organization. OCB is an activity that is considered as a useful activity for the organization (Eisenberg, Davidova, \& Kokina, 2018). It was reaffirmed by Jackson (2009), who described OCB as beneficial behavior for employees, which was not determined but occurred freely to help other people achieve existing tasks and organizational goals.

Thus OCB is a concept that defines certain components of behavior, which stimulate communication between people within the organization and help improve and maximize organizational goals. So that this can be 
simplified into individual voluntary behavior that is not formally recognized in its work responsibilities, but makes a significant contribution to the organization effectively.

\section{Organizational Culture and Organizational Citizenship Behavior (OCB)}

Organizational citizenship behavior is one variable that has been the focus of researchers in recent decades and in various studies the relationship between these variables and various occupations and organizations has been examined (Ebrahimpour, Zahed, Khaleghkhah, \& Sepehri, 2011). According to Badawy, Trujillo, \& Magdy (2017), organizational culture influences several organizational variables in which these variables include organizational citizenship behavior. Research conducted by Pashib, et al (2015) on staff at the university, stated that there was a weak relationship between organizational culture and organizational citizenship behavior in the population studied. Several other studies have shown a significant relationship between the organizational culture and organizational citizenship behavior (Mohanty \& Rath, 2012; Ghashghaeinia \& Hafezi, 2015; Yaseen, Liaquat, Ibn-e-Hassan, \& Hassan, 2015; Patra \& Aima, 2018 )

\section{H1: There is an influence of Organizational Culture on Organizational Citizenship Behavior (OCB)}

\section{Organizational Culture \& Organizational Commitment}

Research conducted by Manetje \& Martins (2009), provides the results of a significant relationship between organizational culture and organizational commitment. Several other studies conducted by several researchers also showed significant results (Mohanty \& Rath, 2012; Setyaningrum, 2017; Patra \& Aima, 2018)

\section{H2: There is an influence of Organizational Culture on Organizational Commitment}

\section{Organizational Commitment and Organizational Citizenship Behavior (OCB)}

Narteh (2012) also specifically defines employee commitment as a feeling of employee attachment to their organization, including their willingness to internalize organizational values and adhere to the rules and regulations in them. Organizational citizenship behavior (OCB) can occur at the individual level and show positive behavior beyond expectations such as helping colleagues even if it is not needed, voluntarily doing additional work, respecting organizational rules and regulations and having tolerance for work-related irregularities and disturbances (Robbins, 2013).

Saraswati \& Sulistiyo (2017), in her research showed significant results on organizational commitment to organizational citizenship behavior.

H3: There is an influence of the Organizational Commitment on Organizational Citizenship Behavior.

\section{Research and Methodology}

This study uses a quantitative approach to test 3 hypotheses, the data collection tool uses a psychological scale, research respondents are car manufacturing employees (Jakarta). The data analysis technique in this study uses path analysis. To get the value of direct and indirect influence used regression analysis with intervening variables. Respondents in this study were 169 employees. In a simple mediation model, the effect of total $X$ on $Y$ is the sum of the direct effect of $X$ on $Y$ and the indirect effect of $X$ on $Y$ to $M$. Where this measurement uses the macro process for mediation developed by Hayes (2018). 


\section{Result and Discussion}

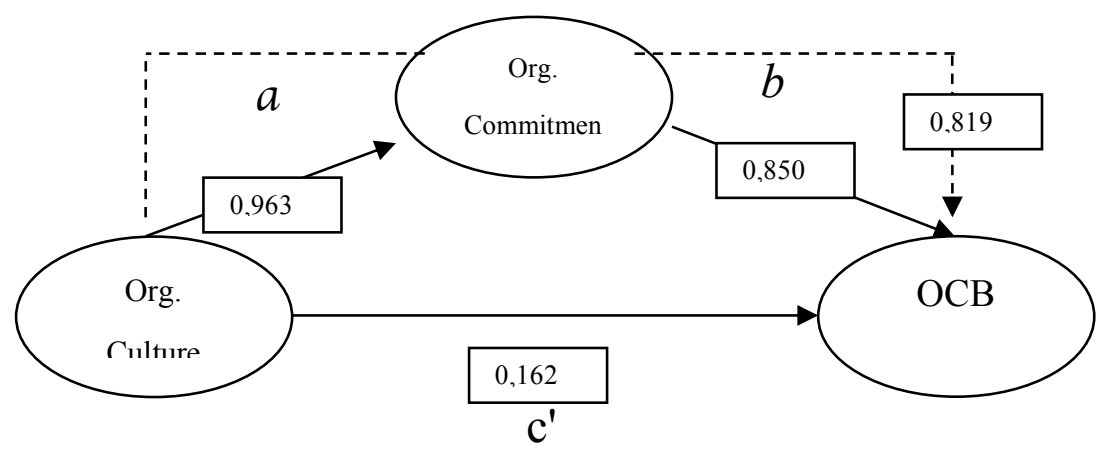

Figure 1: Simple Mediation Model

Table 1: Correlation

\begin{tabular}{|c|c|c|c|c|c|c|}
\hline \multirow[b]{2}{*}{ Antencedent } & \multicolumn{3}{|c|}{ Org.Commitment } & \multicolumn{3}{|c|}{ OCB } \\
\hline & Coeff. & $S E$ & $p$ & Coeff. & $p$ & \\
\hline Org.Culture & a 0.963 & 0.069 & $<.001$ & c' 0.162 & 0.020 & $<.001$ \\
\hline \multirow[t]{3}{*}{ Org.Commitment } & - & - & - & b 0.850 & 0.015 & $<.001$ \\
\hline & \multicolumn{3}{|c|}{$R^{2}=0.535$} & \multicolumn{2}{|l|}{$\mathrm{R}^{2}=0.979$} & \\
\hline & \multicolumn{2}{|c|}{$p=<.001$} & & $p=<.001$ & & \\
\hline
\end{tabular}

The results above in Figure 1. provide standardized beta Organizational Cuture values in the equation (a) of 0.963 and significant (<.005). In the regression equation (c ') the standardized Cut Organizational Cuture value is 0.162 and significant (<.005). The next Organizational Commitment was 0.819 and was significant $(<.005)$.

The results of path analysis (see Figure 1.) show that Organizational Cuture can directly influence Organizational Citizenship Behavior and indirectly influence Organizational Cuture to Organizational Commitment (as an intervening variable) then to Organizational Citizenship Behavior. The amount of direct influence is 0.162 while the magnitude of the indirect influence by diverting the indirect coefficient is 0.819 . Because the indirect correlation coefficient is greater than the direct relationship coefficient, it can be said that the actual relationship is indirect which can be seen in Figure. 1. 
Arumi et al. / International Journal of Research in Business and Social Science,

Vol 8 No 4, 2019 ISSN: 2147-4486

Table 2: Direct \& Inderect Effect

\begin{tabular}{lcccl} 
& Effect & $p$ & LLCl & ULCl \\
\hline Total & 0.981 & 0.000 & 0.861 & 1.101 \\
Direct effect & 0.162 & 0.000 & 0.121 & 0.202 \\
\hline
\end{tabular}

\begin{tabular}{ccccc} 
& Effect & BootSE & BootLLCl & BootULCl \\
\hline Inderect effect & 0.819 & 0.918 & 0.642 & 1.003 \\
\hline Note: LLCl: Lower Level of Confidence Interval; ULCl:Upper Level Confidence Interval; & BootSE:
\end{tabular}

Standard Errors Via Bootstrap;BootLLCI: Lower Level of Confidence Interval Via Bootstrap

BootULCI: Upper Level Confidence Interval Via Bootstrap

To see whether there is a mediating effect or not, we can look at the output in the indirect effect of $\mathrm{X}$ on $\mathrm{Y}$. In figure 2, there is an indirect coefficient of 0.819 . The confidence interval (Confidence Interval / $\mathrm{Cl}$ ) of the bootstrap results is written BootLLCI (lower level for $\mathrm{Cl}$ ) $=0.642$ and BootULCI (upper level for $\mathrm{Cl}$ ) $=1.003$. Basically we ask whether it is possible (with $95 \%$ confidence) that the real indirect effect is zero (which means there is no mediation). If the BootLLCl and BootULCl ranges do not include zero values (0), it can be concluded that the estimation is significant and there is a mediating effect.

From the results of the analysis above, the value of the bootstrap nonstandard effect is 0.819 , and the $95 \%$ confidence interval $(\mathrm{Cl})$ ranges from 0.642 to 1.003 . Because zeros are not included in the $95 \%$ confidence interval, it can be concluded that there is a significant OC indirect effect on OCB through the Commitment. The limitations of this research on small or limited sampling, so the results have not been able to generalize to a greater number. It is hoped that further research will use larger samples.

\section{Discussion}

From the results of the study, it was found that the mediating effect played a very good role. To make the OCBs need to form a good culture and be adapted to the local culture, so that it will bring out a commitment to each employee in the organization. By completing all the elements in organizational culture will form a good organization and can maximize organizational goals. If this happens, then the commitment will appear to every employee that exists. When this commitment arises thus the employees will naturally OCB. The research conducted by Aldrin \& Yunanto (2019), found that even though employees might feel positively about the organizational culture, it does not automatically encourage them to conduct organizational citizenship behavior

This result also shows that organizational culture can influence directly to $\mathrm{OCB}$, but not maximally. Every organization wants each employee to OCB on his organization. A good culture will bring out and increase commitment to each of its employees. Maximum improvement can be seen when the commitment mediates organizational culture and OCB. Employees in the organization will have strong OCB when they have a good commitment, so they realize and do the best for their organization.

\section{Conclusions}

The contribution of organizational culture to the organization which includes the uniqueness of values, behavior, and psychology is needed by the organization. It also includes trust, experience, ways of thinking, and organizational expectations. Improving employee behavior into organizational citizenship behavior is needed by every organization. To bring OCB to employees, a well-formed commitment is needed.Establishing employee commitment to the organization is not easy or difficult. Organizations need to pay attention and reevaluate the current organizational culture. Does the culture meet the needs of the organization or not. Organizations need to reevaluate their organizational culture, so they can pay attention 
to what things can increase their employees' OCB. Commitment is important for the organization, when commitment is formed on organization this will also spread to all people in the organization. Strong commitment cannot be separated from the organizational culture which is formed.

\section{Acknowledgment}

This research received no external funding and authors declare no conflict of interest.

\section{References}

Akopova, S.E., Przhedetskaya, V.N (2016). Imperative of State in the Process of Establishment of Innovational Economy in the Globalizing World. European Research Studies Journal, 19(2), 79-85.

Aldrin, N., \& Yunanto, K. T (2019). Job Satisfaction as a Mediator for the Influence of Transformational Leadership and Organizational Culture on Organizational Citizenship Behavior Abstract :, 3-11. https://doi.org/10.2174/187435010191201

Aly, T., Badawy, E., Kamel, M., \& Hussein, M. M (2016). Exploring the Relationship between Organizational Culture , Job Satisfaction and Organizational Citizenship Behavior. International Journal of Human Resource Studies, (November). https://doi.org/10.5296/ijhrs.v6i4.9939

Azizi, B., Alipour, O., Amin, M., Mehni, K., \& Shojaee, K (2014). Relationship between organizational commitment and organizational citizenship behavior in sport teachers in department of education from Sanandaj Pelagia Research Library Bisotoon Azizi et al Pelagia Research Library, 5(4), 9599.

Badawy, T. A. El, Trujillo-reyes, J. C., \& Magdy, M. M (2017). Exploring the Relationship between Organizational Culture, Organizational Citizenship Behavior and Job Satisfaction : A Comparative Study between Egypt and Mexico. International Journal of Management and Administrative Sciences (IJMAS), 4(06), 1-15.

Balay R, Ipek C (2010). Teachers' perception of organizational culture and organizational commitment in Turkish primary schools. Journal of World of Turks. 2(1): 363-384.

Durna, U. ve Eren, V (2005). Üç baglılık ekseninde örgütsel baglııı. Dogus Üniversitesi Dergisi, 6(2), 210219.

Ebrahimpour, H., Zahed, A., Khaleghkhah, A., \& Sepehri, M. B (2011). A survey relation between organizational culture and organizational citizenship behavior. Procedia - Social and Behavioral Sciences, 30, 1920-1925. https://doi.org/10.1016/j.sbspro.2011.10.373

Eisenberg, A., Davidova, J., \& Kokina, I (2018). The Interrelation between Organizational Learning Culture and Organizational Citizenship Behavior. RURAL ENVIRONMENT. EDUCATION. PERSONALITY, 11(May), 11-12. https://doi.org/10.22616/REEP.2018.043

Ghashghaeinia, A. R., \& Hafezi, S (2015). Relationship between organizational culture and organizational citizenship behavior among personnel of Islamic Azad University of Fars. J. Appl. Environ. Biol. Sci, 5, 131-138.

Hayes, A. F (2018). Introduction to Mediation, Moderation, and Conditional Process Analysis. The Guilford Press New York London.

Hofstede, G (2008). Value Survey Module 2008 manual. IRIC, University of Tilburg, Maastricht, The Netherlands.

Jackson J.C (2009). Organizational Citizenship Behaviors, Collective Teacher Efficiency, and Student Achievement in Elementary Schools (Doctoral Thesis). Virginia: The College of William and Mary.

Luthans, F (2006). Organizational Behavior. Yogyakarta: PenerbitAndi. 
K. S Cameron and S. L Freeman (1991). "Cultural congruence, strength, and type: Relationships to organizational climate and culture," San Francisco: Jossey-Bass.

Khalik, A., Hardhienata, S., \& Sunaryo, W (2016). Relationship between Organizational Culture , Transformational Leadership , Working Motivation to Organizational Commitment. International Journal of Managerial Studies and Research (IJMSR), 4(10), 93-98.

Manetje, O., \& Martins, N (2009). The relationship between organisational culture and organisational commitment. Southern African Business Review, 13(1), 87-111.

Markoczylivia., Xin, K (2004), The virtues of omission in organizational citizenship behavior, university of California I.

Organ D.W., Podsakoff P.M., MacKenzie S.B (2005). Organizational Citizenship Behavior: Its nature, antecedents and consequences. Thousand Oaks, CA: Sage Publications Inc.

Maslach, C., \& Leiter, M. P (2008). Early Predictors of Job Burnout and Engagement. Journal of Applied Psychology, 93(3), 498-512. https://doi.org/10.1037/0021-9010.93.3.498

Mohant, J., \& Rath, B. P (2012). Can Organizational Culture be a Predictor of Organizational Citizenship Behaviors? International Journal of Innovation, Management and Technology, 3(1), 26-29.

Narteh, B (2012). Internal marketing and employee commitment: Evidence from the Ghanaian banking industry. Journal of Financial Services Marketing. 17, 284-30

Naiemah, U., Aris, A. Z. Z., Karim, K. M., Samah, I. H. A., Sa'aban, S., \& Abdul Mutalib, S (2017). Relationships between Organizational Commitment, OCB , Organizational Justice and Turnover Intention: Evidence from Educational Institution in Malaysia. Review of Integrative Business and Economics Research, 6(2), 64-77.

Özdem, G (2012). The relationship between the organizational citizenship behaviors and the organizational and professional commitments OF. Journal of Global Strategic Management, Vol.6, No. 2., 47-64. https://doi.org/10.20460/JGSM.2012615773

Pashib, M., Yaqubi, M., Moharrami, I. seyed, Tatari, M., \& Mohammadi, S (2015). The Relationship between Organizational Culture and Organizational Citizenship Behavior among Staff of Torbat Heydariyeh University of Medical Sciences in 2015. Journal of Torbat Heydariyeh University of Medical Sciences, 3(2), 2015.

Patra, A., \& Aima, M. H (2018). The Effect of Organizational Culture and Job Satisfaction on Organizational Commitments and the Implementation on Organizational Citizenship Behavior in Employees of $\mathrm{Pt}$ . Bali Towerindo Sentra Tbk. International Journal of Scientific and Research Publications, 8(12), 320-328. https://doi.org/10.29322/IJSRP.8.12.2018.p8443

Ryff, C. D., \& Keyes, C. L. M (1995). The Structure of Psychological Well-Being Revisited. Journal of Personality and Social Psychology, 69(4), 719-727. https://doi.org/10.1037/0022-3514.69.4.719

Saraswati, V. A., \& Sulistiyo, S. D (2017). The Influence of Job Satisfaction and Organizational Commitment to the Organizational Citizenship Behavior in PT. Haier Sales Indonesia Bandung Branch. Journal of Engineering and Applied Sciences 12 (2). Medwell Journals.

Schein, E. H (2010). Organizational Culture and Leadership. Jossey-Bass A Wiley Imprint.

Sultanova, V.A., Chechina, S.O (2016). Human Capital as a Key Factor of Economic Growth in Crisis. European Research Studies Journal, 19(2), 72-79.

Robbins, S.P. \& Judge, T. A (2007). Organizational Behavior (12 ed.). Prentice Hall.

Robbins, J (2013), Organizational Behavior. 15th Global Edition. Upper Saddle River, NJ: Pearson.

T. E Deal and A. A Kennedy (1983). "Corporate cultures," Reading, Mass: Addison-Wesley, 19 (4). 
Ubius U, Alas R (2009). Organizational culture types as predictors of corporate social responsibility. Engineering Economics. 61(1): 90-99.

Veličkovska, I (2017). Organizational Citizenship Behavior-Definition, Determinants and Effects. Engineering Management, 3(1), 40-51.

Zeyada, M (2008). Organizational Culture and its Impact on Organizational Performance. International Journal of Academic Research in Business and Social Sciences, 8(3), 349. https://doi.org/10.6007//JARBSS/v8-i3/3939 